\title{
CHLOROPYRIPHOS INTOXICATION ON OXYGEN UPTAKE IN AN AIR BREATHING FISH CLARIAS BATRACHUS
}

\author{
DR. ABARNA ROY
}

Mayurakhshi Gramin College, Ranishwar, Dumka, India

\begin{abstract}
Pollution in freshwater ecosystem has reached high level in these days particularly with reference to the use of pesticides to control pests. Indiscriminate use of these pesticides has endangered the aquatic life. The concentration of these pollutants accumulates through run-off waters in our freshwater bodies, results in harmful effects on aquatic organisms and also upsets the primary productivity.

The dissolved oxygen content of the water is probably the most common measurement of biological significance. The lower oxygen content of the water is a serious limiting factor as it restricts the distribution of animals.

Oxygen is necessary for an animal to perform its various metabolic activities. The intake of oxygen by the animal, depends upon availability in its surrounding medium. The primary cause for the high risk in aquatic system is the depletion in oxygen content. The debt in oxygen content always affects aquatic animals either altering or allowing them to adapt in the changed environment.

The measurement of oxygen uptake is a sensitive method of establishing the relative importance of various environmental changes which is reflected in metabolic rate. Amongst the various factors affecting the metabolic rate in fishes are age and body size

Attempts have also been made to study the effect of various toxicants on the respiratory physiology of fishes. The present work elucidates the acute toxic effects of an insecticide, Chlorpyrifos on haematological parameters and rate of oxygen uptake of Clarias batrachus, in order to find relation with health status and metabolic activity of toxicant exposed fishes.
\end{abstract}

\section{KEYWORDS: Chloropyriphos Intoxication}

Received: Jan 26, 2021; Accepted: Feb 16, 2021; Published: Mar 09, 2021; Paper Id.: IJBRDJUN20211

\section{INTRODUCTION}

\section{MATERIALS AND METHODS}

Live specimen of Clarias batrachus were procured from Dumka fish market. The fishes were acclimatized in the laboratory conditions for a week before experimentation. Care has been taken to keep the animals healthy and free from parasites. The animals were fed daily with the pieces of goat liver. The water temperature during this period was at $30-32.5^{\circ} \mathrm{C}$.The animals were exposed to test concentrations of $0.018750 .0375,0.0754$ and $0.15 \mathrm{ml} / 1$ Chlorpyrifos for $96 \mathrm{hrs}$, during which the pollutant water of each concentrations were renewed afresh every 24 hours.

In the next series of experiment a rectangular acroplex box of approximately 4 litre capacity, having a small air chamber at its top to minimize gaseous exchange at the air water interface, was used (Plate-IX). Under this condition, the fish can obtain air from the small air chamber in addition to extracting oxygen from water through 
gills and skin. The concentration of dissolved oxygen in water samples were determined by Wrinkler's volumetric method (Welch, 1948).

\section{$\mathrm{O}_{2}$ uptake in various Concentrations of Chlorpyrifos}

The effect of Chlorpyriphos on the rate of oxygen uptake was measured at four different concentrations from 0.01875 , $0.0375,0.0754$ and $0.15 \mathrm{ml} / \mathrm{l}$, and a separate control was maintained in fresh aerated tap water. Fishes having almost same body weight (40-50g) were used in the present experiment in order to avoid any change in the rate of oxygen consumption due to body size. Moreover, feeding was stopped at least 24 hours before measuring the rate of oxygen uptake. The $\mathrm{VO}_{2}$ has been expressed in $\mathrm{ml} / \mathrm{kg} / \mathrm{h}$. Ten fishes in each experimental and control group were used and the mean values were compared. The difference of significance, if any was calculated by student's t-test at the level of $5 \%$.

\section{Observation}

The rate of oxygen consumption in Clarias batrachus at different concentrations of Chlorpyrifos exposure under both the experimental conditions (access to air prevented and allowed) are summarized in Table-8. The mean value of $\mathrm{VO}_{2}$ of control animals were $72.44 \pm 1.7276$ and $66.91 \pm 1.5088$ under access to air prevented and allowed conditions respectively (Plate-XII). A perusal of the Table- 8 indicates that exposure of Chlorpyrifos causes an increase in the $\mathrm{VO}_{2}$ but the values are not consistent. There was maximum increase in $\mathrm{VO}_{2}$ at $0.0754 \mathrm{ml} / 1$ exposure of Chlorpyrifos for 96 hours (82.06 1.1843 during access to air prevented condition). There is no correlation between increasing concentrations of Chlorpyrifos with $\mathrm{VO}_{2}$. Maximum rate of oxygen consumption was observed at $0.15 \mathrm{ml} / \mathrm{l}$ Chlorpyrifos exposure in access to air allowed (72.44 \pm 0.7321, P>0.001; (Plate-XII).

\section{DISCUSSION \& RESULTS}

The rate of oxygen consumption in Clarias batrachus at different concentrations of Chlorpyrifos exposure under both the experimental conditions (access to air prevented and allowed) are summarized. The mean value of $\mathrm{VO}_{2}$ of control animals were $72.44 \pm 1.7276$ and $66.91 \pm 1.5088$ under access to air prevented and allowed conditions respectively. There was maximum increase in $\mathrm{VO}_{2}$ at $0.0754 \mathrm{ml} / 1$ exposure of Chlorpyrifos for 96 hours $(82.06 \pm 1.1843$ during access to air prevented condition. There is no correlation between increasing concentrations of Chlorpyrifos with $\mathrm{VO}_{2}$. Maximum rate of oxygen consumption was observed after $0.15 \mathrm{ml} / 1$ Chlorpyrifos exposure in access to air allowed (72.44 \pm 0.7321$)$.

\section{REFERENCES}

1. (Job, 1955; Winberg, 1956; Ojha, et al, 1977), temperature (Beamish, 1964; Rajgopal and Kramer, 1974), season (Wells, 1935; Privolnev, 1948; Pandey, 1978), Ram Deshmukh, D. Ramesh Babu \& K. V. Narasimha Rao "Pressure Testing Results (as a Decision Tool for Deciding Low Oxygen or 533 Ultra-Low Oxygen or High Oxygen Storage) of Semi-hermetically Sealed Controlled Atmosphere Storage Insulated Chambers", International Journal of Mechanical and Production Engineering Research and Development (IJMPERD), Vol. 10, Issue 1, pp, 531-540

2. photoperiod (Robert, 1960; Withy and Saunder, 1973), thyroid (Hoar, 1958; Pritchard and Gorbman, 1960; Gabos, et al,1973) and gonadal activities (Hoar, 1958; Beamish, 1964; Pandey,1976). (Ranke Rybicka, 1975; Hughes, 1975; Waiwood and Johnson, 1974; G. Gnanavel\& P. Muthusamy, "Pharmaceutical Industry Waste Water Treatment using Atmospheric Air and Pure Oxygen" IASET: International Journal of Metallurgical, Materials and Chemical Engineering (IASET: IJMMCE), Vol. 7, Issue 6, pp; 1-6 
3. Kawatski and McDonald, 1974; Lunn, et al, 1976; Pandey, et al, 1976b; Hughes, 1976; Ashis Kumar Panigrahi, Neelanjana Choudhury \& Jayanta Tarafdar, "Elements of Hope and Life in the Poetry of Farrokhzad and Plath”, BEST: International Journal of Humanities, Arts, Medicine and Sciences (BEST: IJHAMS), Vol. 2, Issue 6, pp, 5-10.

4. Singh and Singh, 1977; Reddy, et al, 1977; Pandey, et al, 1979; Choudhary, 1979; Tort, Crespo and Balasch, 1982; Sinhaseni, et al, 1983; Hose, Hunt and Stoffel, 1983; Patil and Kaliwal, 1983; D. K. P Singh, Sumit Kumargupta \& Rashmi Meel, "Study of Oxygen Isotope Effect in Pr, Ca, And Zn Doped Superconductivity YBa2Cu3O7-A”, International Journal of Applied and Natural Sciences (IJANS), Vol. 6, Issue 2, pp; 13-22

5. Pandey, et al, 1984 ;Roy and Datta Munshi, 1988; Srilatha, et al, 1989; Thakur and Pandey 1989 ; Pandey, et al, 2005; Mishra and Thakur,2006:Punam Kumari,2008).

Table

Effect of Acute Toxicity ( $96 \mathrm{hrs}$. Exposure) of Various Concentrations of Chlorpyrifos on Rate of Oxygen Uptake of Clarias batrachus (Linn) $\left(30-32.5^{\circ} \mathrm{C}\right.$; \pm Standard error; $\mathbf{n}=10$ in each group)

\begin{tabular}{|c|c|c|}
\hline Parameters Analysed & $\begin{array}{l}\text { Access to air prevented } \\
(\mathrm{ml} / \mathrm{kg} / \mathrm{hr})\end{array}$ & Access to air allowed $(\mathrm{ml} / \mathrm{kg} / \mathrm{hr})$ \\
\hline Control & $72.44 \pm 1.7276$ & $66.91 \pm 1.5088$ \\
\hline $01875 \mathrm{ml} / \mathrm{l}$ Chlorpyrifos & $76.62 \pm 0.9390 \quad \mathrm{P}>0.001$ & $62.73 \pm 1.5470 \quad P>0.001$ \\
\hline $0.0375 \mathrm{ml} / / \mathrm{Chlorpyrifos}$ & $78.84 \pm 0.6023 \quad P>0.001$ & $60.21 \pm 1 . .3420 \mathrm{P}>0.001$ \\
\hline $0.0754 \mathrm{ml} / \mathrm{l}$ Chlorpyrifos & $82.06 \pm 1.1843 \mathrm{P}>0.001$ & $56.75 \pm 1.3640 \mathrm{P}>0.001$ \\
\hline $0.15 \mathrm{ml} / \mathrm{l}$ Chlorpyrifos & $67.95 \pm 1.1843 \mathrm{P}>0.001$ & $72.44 \pm 0.7321 \mathrm{P}>0.001$ \\
\hline
\end{tabular}

\section{PLATE-XI}

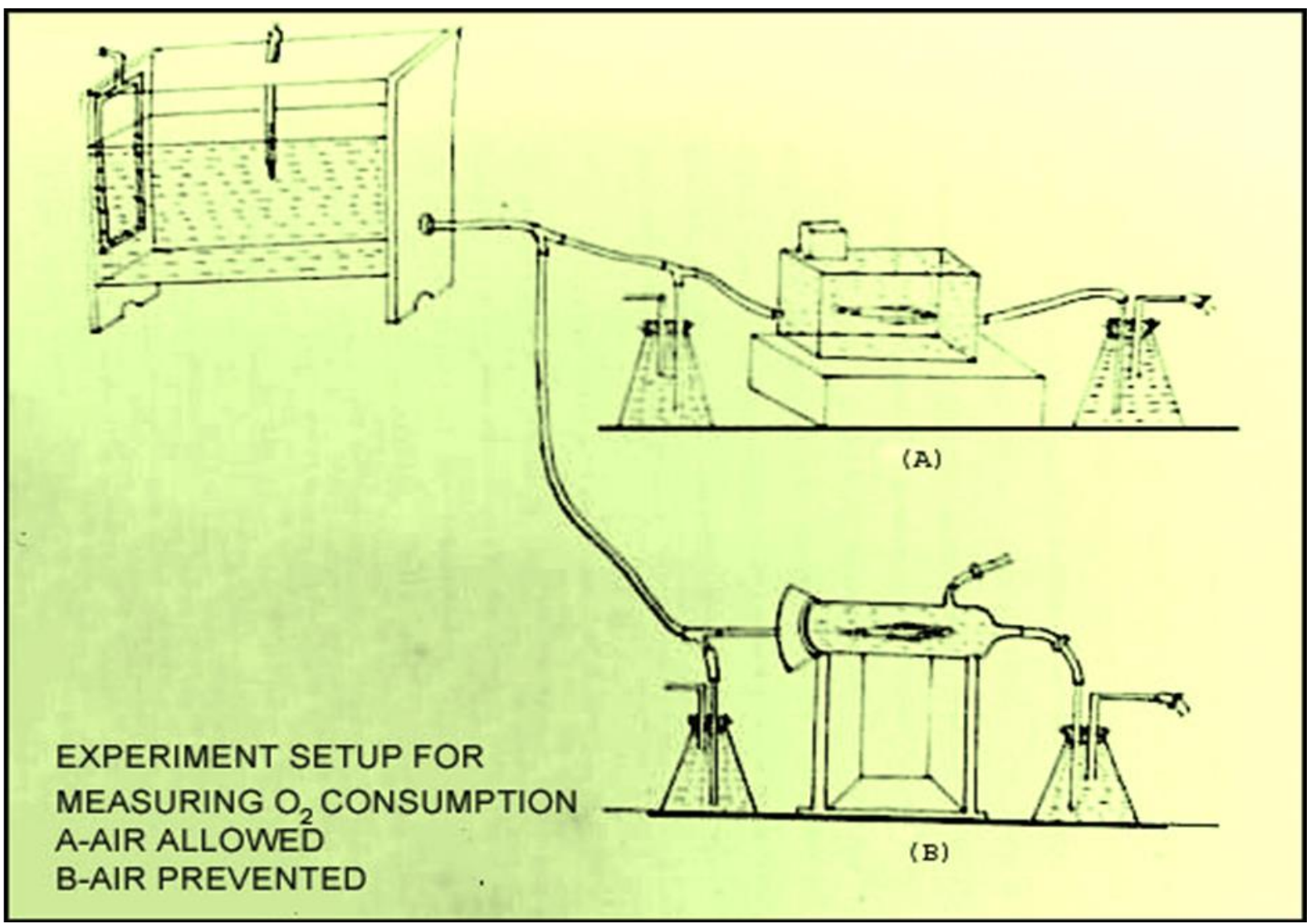




\section{EXPLANATION OF PLATE-XI}

Diagram of the apparatus used to determine the $\mathrm{O}_{2}$ Uptake by the fish under access to air allowed and prevented conditions.

\section{PLATE- XII}

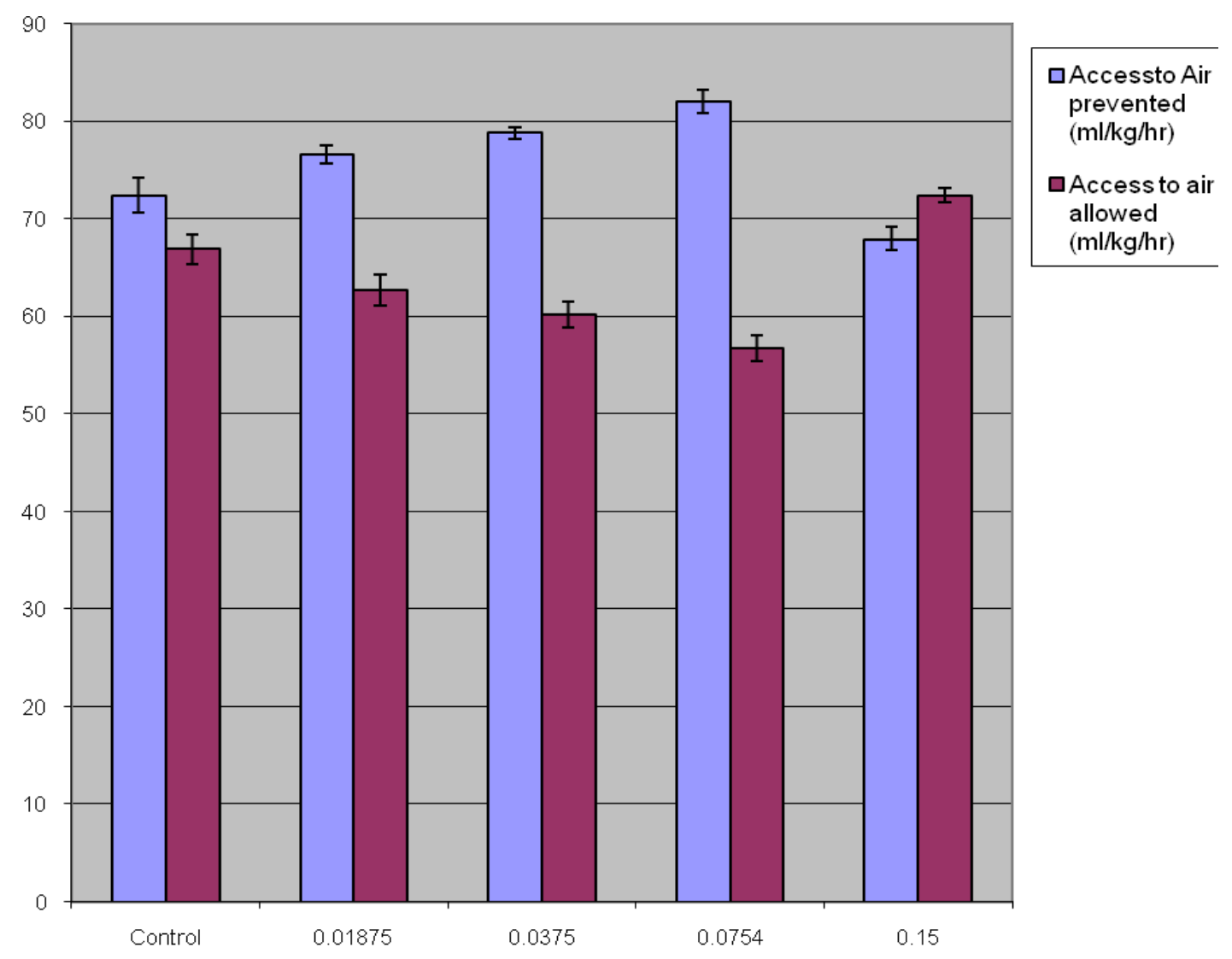

\section{SHOWING THE EFFECT OF VARIOUS CONCENTRATIONS OF CHLORPYRIPHOS ON THE RATE OF OXYGEN UPTAKE OF CLARIAS BATRACHUS DURING ACCESS TO AIR ALLOWED AND PREVENTED CONDITIONS}

\section{EXPLANATION OF PLATE-XII}

Histograms showing the effect of various concentrations of Chlorpyrifos exposure for 96 hours on the rate of Oxygen uptake during access to air prevented and access to air allowed in C. batrachus. 